Research Article

\title{
Double-Layered Zirconia Films for Carbon-Based Mesoscopic Perovskite Solar Cells and Photodetectors
}

\author{
George Syrrokostas $\mathbb{D}^{1},{ }^{1}$ George Leftheriotis, ${ }^{2}$ and Spyros N. Yannopoulos $\mathbb{D}^{1}$ \\ ${ }^{1}$ Foundation for Research and Technology Hellas, Institute of Chemical Engineering Sciences (FORTH/ICE-HT), \\ Patra GR-26504, Greece \\ ${ }^{2}$ Department of Physics, University of Patras, Patra GR-26504, Greece \\ Correspondence should be addressed to George Syrrokostas; gesirrokos@iceht.forth.gr
}

Received 29 December 2018; Revised 31 March 2019; Accepted 8 April 2019; Published 22 May 2019

Academic Editor: Jianbo Yin

Copyright (c) 2019 George Syrrokostas et al. This is an open access article distributed under the Creative Commons Attribution License, which permits unrestricted use, distribution, and reproduction in any medium, provided the original work is properly cited.

\begin{abstract}
Carbon-based mesoscopic perovskite solar cells (PSCs) and photodetectors were fabricated with the application of double-layered $\mathrm{ZrO}_{2}$ films, consisting of zirconia nanoparticles and microparticles for the first and the second layer, respectively. This assembly exploits the ability of the zirconia microparticles to scatter and hence diffuse the incident light, causing a more efficient illumination of the perovskite layer. As a result, the photocurrent densities produced by a photodetector and a carbon-based PSC were increased by nearly $35 \%$ and $28 \%$, respectively, compared to devices assembled using a conventional single zirconia film. Following the increase in the photocurrent, the responsivity of the photodetector and the power conversion efficiency of the PSC were increased analogously, due to the improved light harvesting efficiency of the perovskite layer. Parameters, such as the total thickness, the roughness, and the crystallinity of the films, were examined. Differences in the grain size and in the crystal planes of the perovskite were observed and evaluated. These results demonstrate that a double-layered $\mathrm{ZrO}_{2}$ film can enhance the efficiency of solar cells and photodetectors, enhancing the prospects for their potential commercialization.
\end{abstract}

\section{Introduction}

Solar cells based on organolead halide perovskites (PSC) have attracted the intense interest of researchers worldwide during the last several years. This intensive research work has led to certified power conversion efficiencies exceeding $20 \%[1,2]$. The main component of these devices is the perovskite layer, acting both as a light harvester and charge transport material. The high efficiency obtained arises from the excellent optoelectronic properties of the perovskite layer, such as high absorbance of the incident light over a broad range covering the visible and the near-infrared spectrum, long carrier diffusion length and high carrier mobility, transport of both electrons and holes, and low exciton binding energy [3-6].

Several device architectures have been proposed up to now in an effort to achieve increased efficiency $[3,7,8]$. Among them, the carbon-based mesoscopic perovskite solar cells offer a promising solution towards potential commercialization
$[6,8]$. A typical solar cell consists of a transparent conductive glass electrode (FTO or ITO), an electron transport layer (ETL, usually $\mathrm{TiO}_{2}$ or $\mathrm{ZnO}$ ), a layer based on $\mathrm{ZrO}_{2}$ or $\mathrm{Al}_{2} \mathrm{O}_{3}$ acting as a spacer, and finally a carbon electrode (Figure 1) $[9,10]$. The various layers are mesoporous and are deposited sequentially on top of each other, followed by high-temperature annealing. Finally, the perovskite penetrates inside the mesoporous structure, by drop casting a perovskite precursor solution on top of the carbon electrode.

In the above devices, a hole transport layer (HTL) is absent; thus, holes are transported through the perovskite layer to the carbon electrode. The absence of an expensive and unstable HTL, such as spiro-Ometad, and the lack of gold metal electrodes are among the advantages of this device architecture. Further advantages include good stability, preparation of devices using printable techniques under environmental conditions, and the relatively low cost $[6,11,12]$. On the other hand, their efficiency is lower than that of devices 


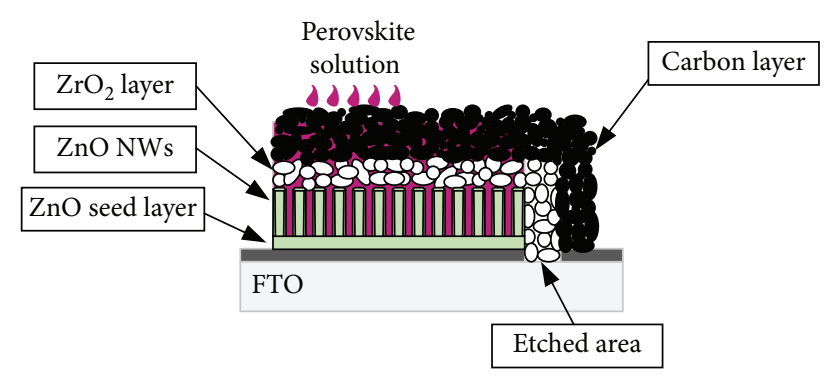

FIGURE 1: Schematic structure of a carbon-based PSC using ZnO NW arrays as an electron transport layer (ETL).

with a HTL $(<16 \%$ [3]); hence, certain issues have to be resolved to improve their performance and their competitive advantages which could lead to potential commercialization $[3,6,8]$.

Of the different layers used in this architecture, the spacer layer plays an important role, namely, to prevent direct contact between the ETL and the carbon layer, acting as an insulator, and thus, its morphology is crucial. For example, there is an optimum thickness of the spacer layer in order to prepare high-efficiency devices $[5,13,14]$, since the perovskite inside the pores of the spacer layer also absorbs part of the incoming light and the photogenerated electrons have to be transferred to ETL and holes to the carbon electrode, through the perovskite layer. Liu et al. [5] found that the efficiency was maximized when the thickness of the $\mathrm{ZrO}_{2}$ layer was $1 \mu \mathrm{m}$.

Moreover, an uneven spacer layer would increase the probability of direct contact between ETL and carbon film. Liu et al. [15] prepared a flat and uniform spacer layer consisting of $\mathrm{TiO}_{2} @ \mathrm{ZrO}_{2}$ core shell nanoparticles, achieving better insulating properties and a defect-free flat interface between carbon electrode and perovskite.

The properties of the spacer layer can also affect the morphology of the perovskite layer, since the latter is confined in the mesoporous spacer film. Meng et al. [4] used $\mathrm{ZrO}_{2}$ and $\mathrm{Al}_{2} \mathrm{O}_{3}$ as spacer layers and found that the larger pores of the $\mathrm{ZrO}_{2}$ layer are more favorable for the infiltration and crystallization of the perovskite, generating large grains, thus reducing the crystal boundaries.

Finally, a thick $\mathrm{ZrO}_{2}$ layer can replace the mesoporous ETL, in an effort to simplify the manufacturing procedure, by reducing the number of layers and the number of annealing steps. Devices without the mesoporous ETL have showed efficiencies up to $9.7 \%$ [14]. On the other hand, in some cases, the $\mathrm{ZrO}_{2}$ layer is absent. Then, to avoid a possible short circuit of the device, the growth of a compact and even perovskite film between the ETL and the carbon layer is necessary $[15,16]$, since otherwise undesirable internal losses could lead to low efficiency of the device.

In the current study, a double-layered film consisting of $\mathrm{ZrO}_{2}$ nanoparticles and microparticles was used as a spacer layer for carbon-based PSCs. The light-scattering effect of $\mathrm{ZrO}_{2}$ microparticles has been applied for the first time, as a method to enhance light fluence on the perovskite layer. In the presence of this layer, a fraction of light transmitted through the perovskite layer can be reflected back [17], thus increasing the light fluence irradiating the perovskite. Reflection of light also takes place, when a gold electrode is used in other device architectures [6]. As a result, an efficiency improvement up to $30 \%$ was observed due to better light trapping from the double-layered $\mathrm{ZrO}_{2}$ film, compared to a conventional spacer based on $\mathrm{ZrO}_{2}$ nanoparticles. Finally, novel photodetectors having a simple structure of FTO/Z$\mathrm{rO}_{2}$ /perovskite/FTO have been prepared, to explore simultaneously the light absorption ability and charge transport properties of the $\mathrm{ZrO}_{2}$ /perovskite system.

\section{Materials and Methods}

2.1. Materials and Preparation of $\mathrm{ZnO} N W$ Arrays. ZnO NW arrays were grown on conductive glass substrates (FTO, $R_{\mathrm{sh}}$ $=15 \Omega /$ sq, supplied by GreatCell Solar), using a method reported in our previous work [18]. First, the conductive side was patterned using zinc powder and $\mathrm{HCl}$ acid solution $(20 \%$ $v / v)$, to form two electrically isolated areas, and then, the substrates were cleaned using a standard procedure $[18,19]$. After cleaning, a seed layer was prepared on the conductive side of the substrates by spin coating, using a solution containing $0.05 \mathrm{M}$ zinc acetate dihydrate $\left(\mathrm{Zn}\left(\mathrm{CH}_{3} \mathrm{COO}\right)_{2} \cdot 2 \mathrm{H}_{2} \mathrm{O}\right.$, Merck, 98\%) in absolute ethanol. Each time, five drops of the solution were spin coated at $1000 \mathrm{rpm}$ for $30 \mathrm{~s}$ and the procedure was repeated five times. The films were subsequently annealed at $300^{\circ} \mathrm{C}$ for $120 \mathrm{~min}$ to achieve their decomposition to $\mathrm{ZnO}$ seed nanocrystals.

The seeded substrates were placed in an aqueous solution, with a total volume of $15 \mathrm{ml}$, containing $50 \mathrm{mM}$ zinc nitrate hexahydrate $\left(\mathrm{Zn}\left(\mathrm{NO}_{3}\right)_{2} \cdot 6 \mathrm{H}_{2} \mathrm{O}\right.$, Merck, 98\%), $25 \mathrm{mM}$ hexamethylenetetramine $\left(\mathrm{C}_{6} \mathrm{H}_{12} \mathrm{~N}_{4}\right.$, HMT, Merck), $0.45 \mathrm{M}$ $\mathrm{NH}_{4} \mathrm{OH}$, and $0.03 \mathrm{~g}$ PEI $(\mathrm{MW}=800)$. The seeded substrates were placed in the growth solution facing down and inserted in an oven at $88^{\circ} \mathrm{C}$ for $50 \mathrm{~min}$. Finally, after growth, the substrates were rinsed with triple deionized (3D) water and annealed at $300^{\circ} \mathrm{C}$ for $2 \mathrm{~h}$.

2.2. Materials and Preparation of $\mathrm{ZrO}_{2}$ and Carbon Pastes. For the preparation of the $\mathrm{ZrO}_{2}$ pastes, either a commercial $\mathrm{ZrO}_{2}$ nanopowder $(0.8 \mathrm{~g})$ with particle diameter $d=15$ $-25 \mathrm{~nm}$ (99\%, Alfa Aesar) or a $\mathrm{ZrO}_{2}$ powder $(0.8 \mathrm{~g})$ consisting of microparticles (99.7\%, Cerac Z-1074) was ground in a porcelain mortar initially with a small volume of $3 \mathrm{D}$ water $(0.5 \mathrm{ml})$, while afterwards ethanol $(5 \mathrm{ml})$ was added dropwise under continuous grinding for at least $15 \mathrm{~min}$. The paste prepared in that way was transferred to a beaker by adding $20 \mathrm{ml}$ of ethanol and stirred at $90-100^{\circ} \mathrm{C}$, until nearly complete evaporation of ethanol and water was achieved. Finally, $3 \mathrm{~g}$ of a $10 \mathrm{wt} \%$ ethyl cellulose solution in EtOH (Sigma-Aldrich, viscosity $22 \mathrm{cP}$ ), acting as a binder, and $2 \mathrm{~g}$ a-terpineol (Sigma-Aldrich, analytical standard) were added, followed again by stirring at $90-100^{\circ} \mathrm{C}$ to achieve the desired viscosity of the paste.

A similar method was used for the preparation of the carbon paste, where $0.4 \mathrm{~g}$ of graphite powder $(99 \%, 7-11 \mu \mathrm{m}$, Alfa Aesar), $0.25 \mathrm{~g}$ carbon black (Vulcan XC-72), and $0.05 \mathrm{~g}$ $\mathrm{ZrO}_{2}$ nanopowder were ground in a porcelain mortar with $1 \mathrm{ml}$ of $3 \mathrm{D}$ water and $3 \mathrm{ml}$ of ethanol. After transferring to a 
beaker by adding $30 \mathrm{ml}$ of ethanol and stirring at $90-100^{\circ} \mathrm{C}$, ethyl cellulose $(3 \mathrm{~g}, 10 \mathrm{wt} \%$ in EtOH) and a-terpineol $(2 \mathrm{~g})$ were added, followed again by stirring at $90-100^{\circ} \mathrm{C}$ to achieve the desired viscosity of the paste.

2.3. Fabrication of the Devices. $\mathrm{A} \mathrm{ZrO}_{2}$ film $\left(\mathrm{N} \_\mathrm{ZrO}_{2}\right)$ was deposited on the grown $\mathrm{ZnO} \mathrm{NW}$ arrays, via the doctor blade method, using the paste with the zirconia nanoparticles. The films were annealed at $400^{\circ} \mathrm{C}$ for $1 \mathrm{~h}$. After cooling at room temperature, deposition of the carbon paste followed, ensuring that the carbon film was attached to the side of the patterned substrate serving as cathode (Figure 1). Finally, the films were annealed at $400^{\circ} \mathrm{C}$ for $30 \mathrm{~min}$, in order to thermally decompose the organic ingredients used for the preparation of the carbon paste, since the as-prepared carbon films were nonconductive. For the preparation of the doublelayered $\mathrm{ZrO}_{2}$ film (DL_ZrO 2 ), on the surface of $\mathrm{N} \_\mathrm{ZrO}_{2}$ film, a second layer was deposited with the doctor blade method, using the $\mathrm{ZrO}_{2}$ paste with the microparticles. After annealing at $400^{\circ} \mathrm{C}$ for $30 \mathrm{~min}$, a carbon film was deposited to complete the devices.

A small amount $(10 \mu \mathrm{l})$ of a perovskite precursor solution (1.3 M methylammonium iodide and $1.3 \mathrm{M}$ lead iodide in $\gamma$-GBL) was added dropwise on top of the carbon film (Figure 1). The perovskite solution was infiltrated through the porous network of the films, and the samples were annealed at $80^{\circ} \mathrm{C}$ for $30 \mathrm{~min}$ to achieve crystallization of the perovskite.

2.4. Characterization Methods. The morphologies of the films were evaluated using field emission scanning electron microscope (FE-SEM) (FEI Inspect TM F50). The crystal structures were investigated using X-ray diffraction (XRD) (Bruker D8 diffractometer), operating at $40 \mathrm{kV}$ and $40 \mathrm{~mA}$, employing $\mathrm{Cu} \mathrm{Ka}$ radiation $(\lambda=1.54056 \AA)$. The thickness and the roughness $\left(R_{a}\right)$ of the films were measured by an Ambios XP-1 stylus profilometer, while a UV-Vis spectrophotometer (Hitachi, U-3010) was used for measuring the absorbance of the films at normal incidence.

The $J-V$ curves of the prepared solar cells were recorded with the use of an Oriel 96000 solar simulator, equipped with an AM1.5G filter, in conjunction with a Keithley 236 source meter. The incident irradiance was fixed at $1000 \mathrm{~W} / \mathrm{m}^{2}[19,20]$. The $J-V$ and the transient photocurrent curves of the prepared photodetectors were recorded using a LED lamp (warm white, $30 \mathrm{~W}$ ) and a potentiostat (Princeton Applied Research, Model 263A). The incidence irradiance in this case was fixed at $7.5 \mathrm{~mW} / \mathrm{cm}^{2}$, as measured by a thermal power sensor (S322C, Thorlabs) using a PM100D power console.

\section{Results and Discussion}

3.1. Film Morphology. The morphologies of the different films are illustrated in Figure 2, starting from the $\mathrm{ZnO}$ NW arrays (Figure 2(a)), the carbon film (Figure 2(b)), and the $\mathrm{ZrO}_{2}$ films (Figures 2(c) and 2(d)), prepared using the microparticles (MPs) or the nanoparticles (NPs), respectively. The average diameter and the length of the NWs are
$55 \pm 10 \mathrm{~nm}$ and $0.8 \pm 0.2 \mu \mathrm{m}$, respectively. Similarly, the average thickness of the carbon films is $25 \pm 3 \mu \mathrm{m}$, comprised of nanoparticles with size $60-70 \mathrm{~nm}$. The differences between the two $\mathrm{ZrO}_{2}$ films are noticeable. A rough morphology and particles with size ranging from 0.5 to $2.0 \mu \mathrm{m}$ (Figure S1) appear for the $\mathrm{ZrO}_{2}$ film with the microparticles, while a more even morphology appears for the $\mathrm{ZrO}_{2}$ film with the nanoparticles.

The crystal structure of the $\mathrm{ZrO}_{2}$ films has been examined by XRD. Figure 3(a) presents the diffraction pattern for the films prepared using $\mathrm{ZrO}_{2}$ microparticles (MPs) or nanoparticles (NPs), deposited on a glass substrate. For both films, the main diffraction peaks appear at $28.5^{\circ}$ and at $31.8^{\circ}$, assigned to crystal planes (-111) and (111), respectively, of monoclinic zirconia $[21,22]$. In the case of the $\mathrm{ZrO}_{2}$ microparticles, the peaks are sharper, indicating an increased crystallinity and that the film consists of larger crystallites (Figure 3(b)). According to the Scherrer equation [19, 21], the size of the crystallites is $19.5 \mathrm{~nm}$ and $20.8 \mathrm{~nm}$ or $41.2 \mathrm{~nm}$ and $40.5 \mathrm{~nm}$, if the FWHM of diffraction peak at $2 \theta=28.5^{\circ}$ or at $2 \theta=31.8^{\circ}$ is used for the calculations, in the case of $\mathrm{ZrO}_{2} \mathrm{NPs}$ and $\mathrm{ZrO}_{2} \_\mathrm{MPs}$, respectively (Figure 3(b)). Moreover, the position of the other peaks and their number are the same for both films, showing the similar crystal structure.

3.2. Morphology of the Perovskite Layer Deposited on the Surface of $\mathrm{ZrO}_{2}$ Films. The morphology of the perovskite layers, deposited on the surface of a double-layered $\mathrm{ZrO}_{2}$ film $\left(\mathrm{DL} \_\mathrm{ZrO}_{2}\right)$ and on the surface of a normal $\mathrm{ZrO}_{2}$ film $\left(\mathrm{N}_{-}\right.$ $\mathrm{ZrO}_{2}$ ), is illustrated in Figures 4(a) and 4(b), respectively. In both cases, most grains of $\mathrm{CH}_{3} \mathrm{NH}_{3} \mathrm{PbI}_{3}$ have size less than $50 \mu \mathrm{m}$ (Figures $4(\mathrm{c})$ and $4(\mathrm{~d})$ ). Nevertheless, in the case of the $\mathrm{DL}_{-} \mathrm{ZrO}_{2}$ film, larger grains with size exceeding $100 \mu \mathrm{m}$ are evident in contrast to the $\mathrm{N}_{-} \mathrm{ZrO}_{2}$ film. Largersized perovskite crystals favor charge transport, due to the presence of fewer grain boundaries [23, 24]. The surface of the $\mathrm{DL} \_\mathrm{ZrO}_{2}$ film consists of $\mathrm{ZrO}_{2}$ microparticles, with large gaps between them. As a result, the free space between them is filled initially with the perovskite solution and permits the growth of large grains of $\mathrm{CH}_{3} \mathrm{NH}_{3} \mathrm{PbI}_{3}$. The grainy morphology of the perovskite layer is a characteristic of the method used for its preparation, using a one-step deposition method from a precursor solution of $\mathrm{PbI}_{2}$ and $\mathrm{CH}_{3} \mathrm{NH}_{3} \mathrm{I}$ in $\gamma$-GBL $[5,24,25]$.

The crystal structures of the perovskite layers after deposition on the surface of the two different $\mathrm{ZrO}_{2}$ films are illustrated in Figure 5 and Figure S2 (closer view). The peaks at $13.98^{\circ}, 14.1^{\circ}, 20^{\circ}, 23.5^{\circ}, 28.2^{\circ}, 31.5^{\circ}, 40.5^{\circ}$, and $43.1^{\circ}$ are assigned to (002), (110), (112), (211), (004), (114), (224), and (314) crystal planes of $\mathrm{CH}_{3} \mathrm{NH}_{3} \mathrm{PBI}_{3}$, respectively $[26,27]$, showing a perovskite layer with a tetragonal crystal structure. No peaks assigned to $\mathrm{PbI}_{2}$ are observed [28], showing the efficient formation of the perovskite by the one-step method. The only difference observed is that the main peaks in the case of $\mathrm{N} \_\mathrm{ZrO}_{2}$ film are (002), (110), and (211), while in the case of the $\mathrm{DL} \_\mathrm{ZrO}_{2}$ film, the main peaks are (110), (004), and (114), revealing a difference in the crystal orientation. 


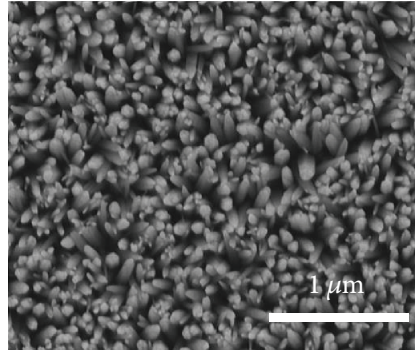

(a)

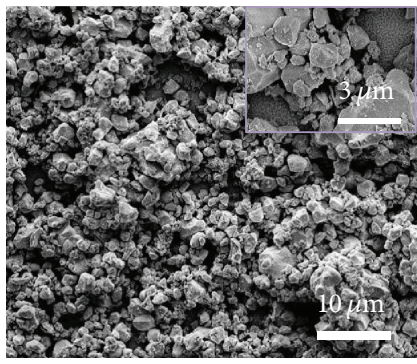

(c)

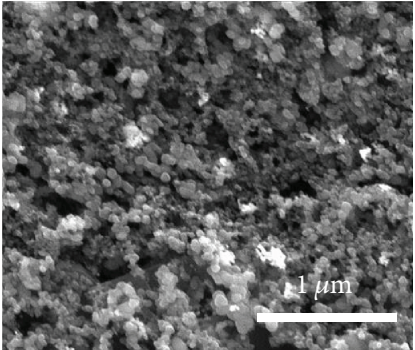

(b)

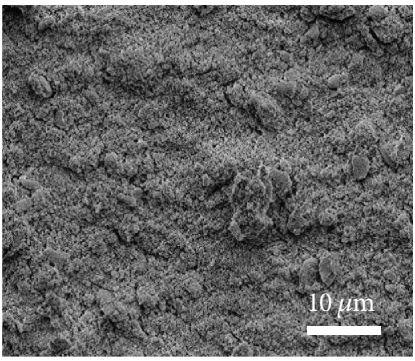

(d)

Figure 2: SEM images of (a) $\mathrm{ZnO} N W$ arrays, (b) carbon film, (c) $\mathrm{ZrO}_{2}$ film using microparticles, and (d) $\mathrm{ZrO}_{2}$ film using nanoparticles.

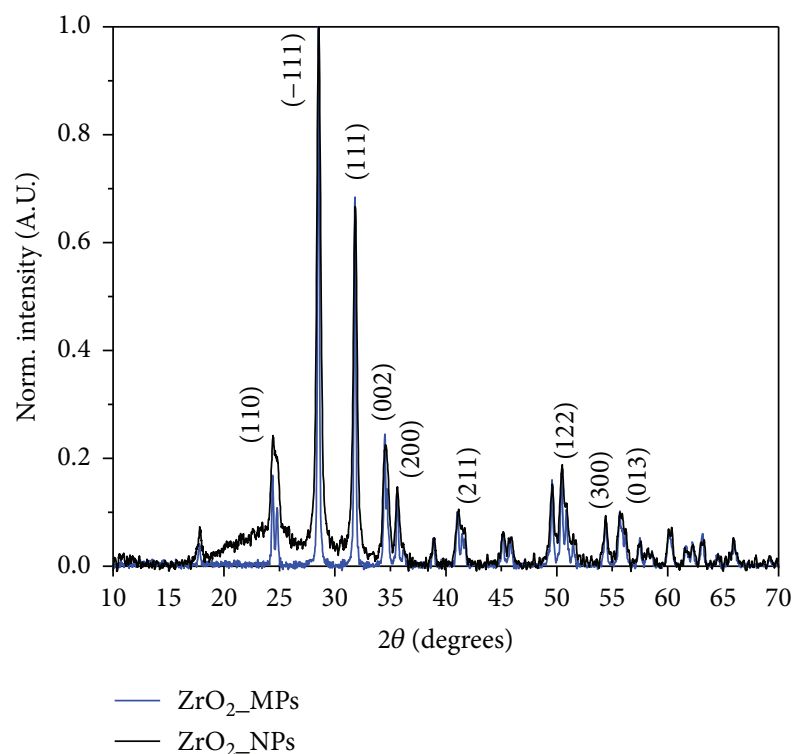

(a)

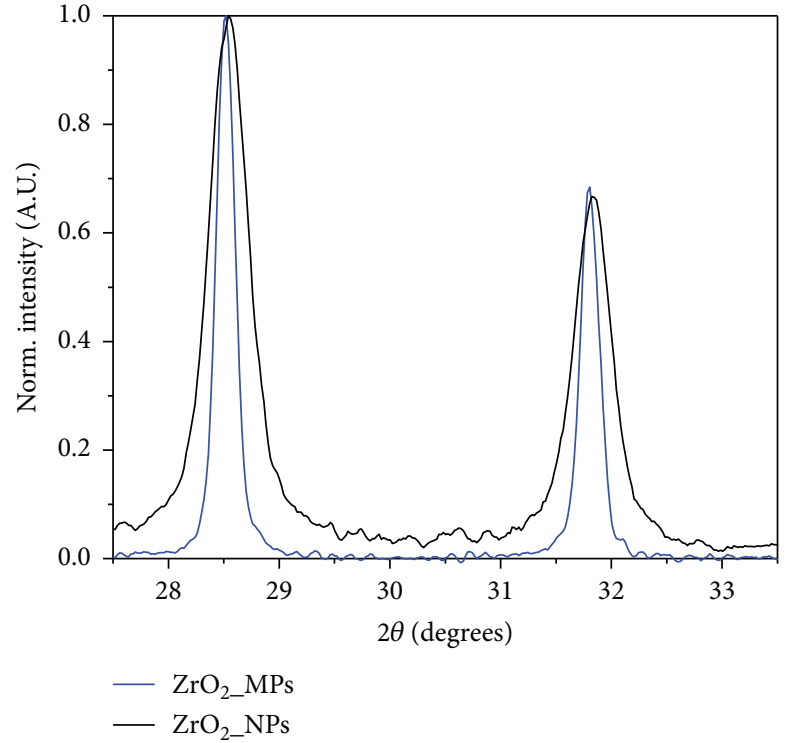

(b)

Figure 3: (a) XRD pattern of the two different $\mathrm{ZrO}_{2}$ films deposited on glass. (b) Magnification of the two main diffraction peaks.

3.3. Optical Properties. The UV-Vis absorption spectra of the $\mathrm{N} \_\mathrm{ZrO}_{2}$ and DL_ZrO $\mathrm{Z}_{2}$ films deposited on glass (Figure 6(a)) reveal an increased absorbance, covering all the visible and the near-infrared region, from $400 \mathrm{~nm}$ to $800 \mathrm{~nm}$, in the second case. The average film thickness and roughness $\left(R_{a}\right)$ are $2.1 \mu \mathrm{m}$ and $0.54 \mu \mathrm{m}$ for the $\mathrm{N} \_\mathrm{ZrO}_{2}$ and $2.7 \mu \mathrm{m}$ and $0.64 \mu \mathrm{m}$ for the DL_ZrO film (Figure 6(b)). As a result, the thickness of the scattering layer consisting of $\mathrm{ZrO}_{2} \mathrm{MPs}$ is only $600 \mathrm{~nm}$.

The increased absorbance for the $\mathrm{DL}_{2} \mathrm{ZrO}_{2}$ film is ascribed to the higher scattering ability owing to the size of the particles. Indeed, particles with an average size comparable with the wavelength of light are more efficient scatterers [29]. The presence of the large $\mathrm{ZrO}_{2}$ particles in the doublelayered spacer film results in an increase of the optical path length, due to the improved scattering efficiency [17, 30-32]. Moreover, scattering of light is more intense as the wavelength of light decreases, as expected from Rayleigh and Mie scattering theory. Finally, in the case of the doublelayered spacer film, the absorbance is nearly steady from $800 \mathrm{~nm}$ to $400 \mathrm{~nm}$. 


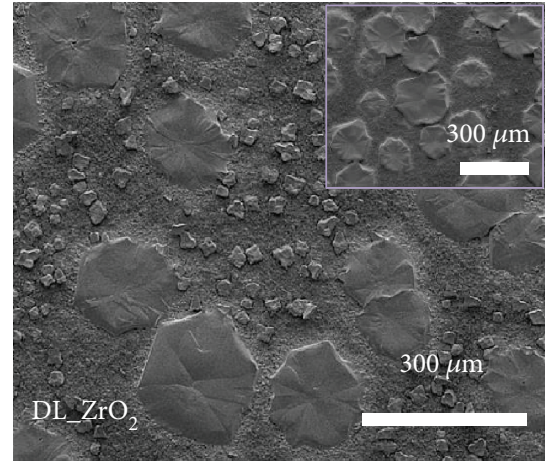

(a)

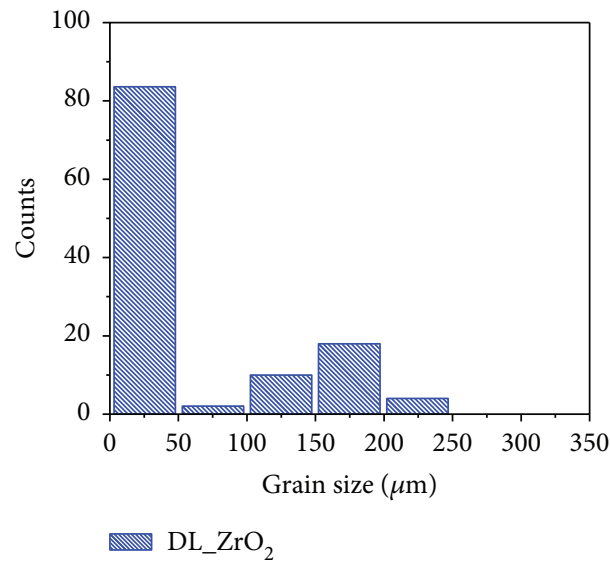

(c)

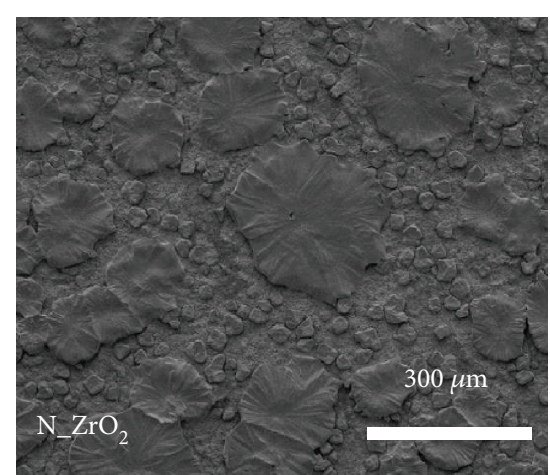

(b)

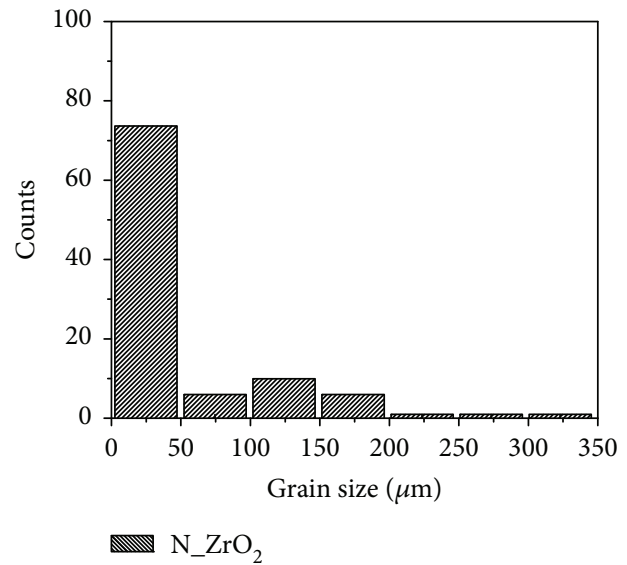

(d)

Figure 4: SEM images of (a) the perovskite layer deposited on the surface of a DL_ZrO film (inset: SEM image from a different area) and (b) on the surface of a $\mathrm{N} \_\mathrm{ZrO}_{2}$ film $\left(80^{\circ} \mathrm{C} / 1 \mathrm{~h}\right)$. (c) Distribution of grain size in the case of a $\mathrm{DL} \_\mathrm{ZrO}_{2}$ film and (d) distribution of grain size of a $\mathrm{N} \_\mathrm{ZrO}_{2}$ film.

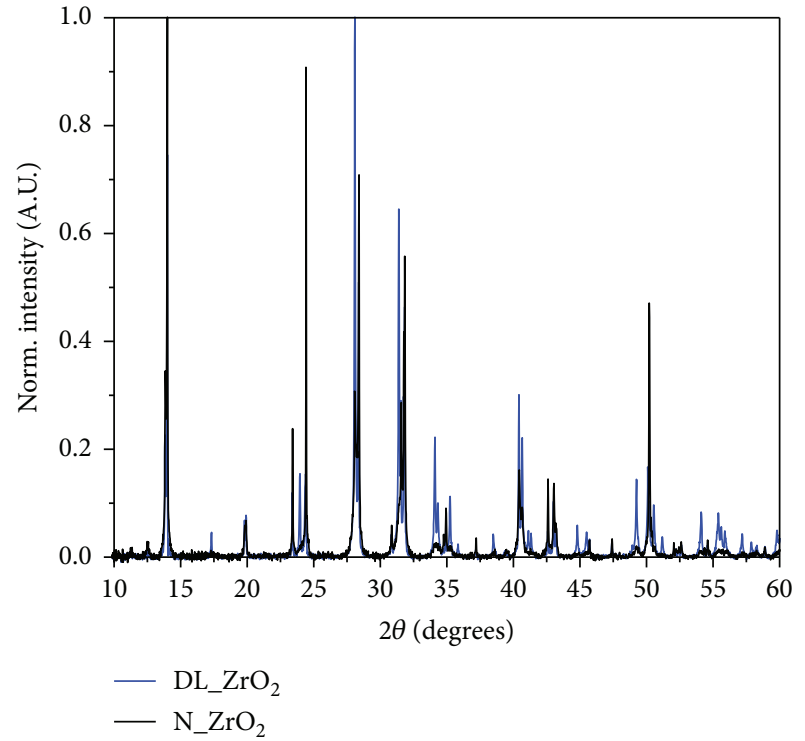

FIGURE 5: XRD pattern of the perovskite layer deposited on the surface of the two different $\mathrm{ZrO}_{2}$ layers.
3.4. Performance of Photodetectors. To evaluate the absorption ability and the charge carrier mobility of the perovskite layer in the presence of the two different $\mathrm{ZrO}_{2}$ layers, independently from the development of carbon-based PSCs, photodetectors having the structure $\mathrm{FTO} / \mathrm{ZrO}_{2} /$ perovskite/FTO (Figure 7) were prepared. In this configuration, the $\mathrm{ZrO}_{2}$ layer serves as a scaffold for the deposition of the perovskite. Both light absorption and charge transport take place only through the perovskite layer, since electron transport from the perovskite to the $\mathrm{ZrO}_{2}$ is inhibited due to the positions of the energy bands [33].

Figure 7 illustrates the $J-V$ curves of $\mathrm{ZrO}_{2} /$ perovskite photodetectors under illumination, using a LED lamp with an intensity of $7.5 \mathrm{~mW} / \mathrm{cm}^{2}$. The linear response of the photocurrent in response to the applied bias potential indicates the formation of ohmic contacts between the perovskite and the FTO electrodes (Figure $7(\mathrm{a})$ ). The distance between the two electrodes is $1.8 \mathrm{~cm}$, far from being optimized, since the distance between the electrodes is usually few tens of $\mu \mathrm{m}$ [34-36]. Nevertheless, the photocurrent density produced at a bias potential of $1 \mathrm{~V}$ (Figure $7(\mathrm{~b})$ ) in the case of the DL_Z $\mathrm{rO}_{2}$ film is nearly $325 \mathrm{nA} / \mathrm{cm}^{2}$, almost $35 \%$ larger than the photocurrent density produced in the case of the $\mathrm{N} \_\mathrm{ZrO}_{2}\left(240 \mathrm{nA} / \mathrm{cm}^{2}\right)$. As a result, the responsivity of the 


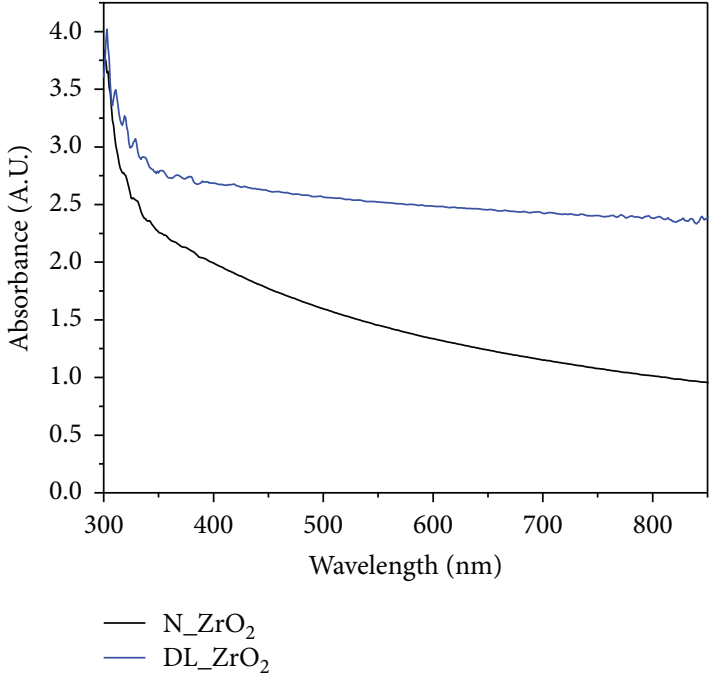

(a)

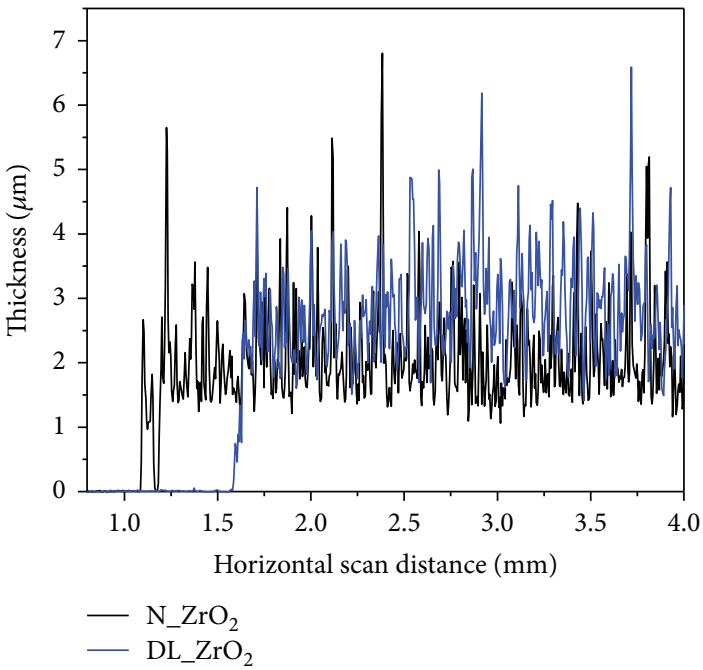

(b)

FIgURE 6: (a) UV-Vis absorbance spectra of $\mathrm{N} \_\mathrm{ZrO}_{2}$ and a $\mathrm{DL} \_\mathrm{ZrO}_{2}$ films, deposited on glass, and (b) film thickness of the corresponding films.

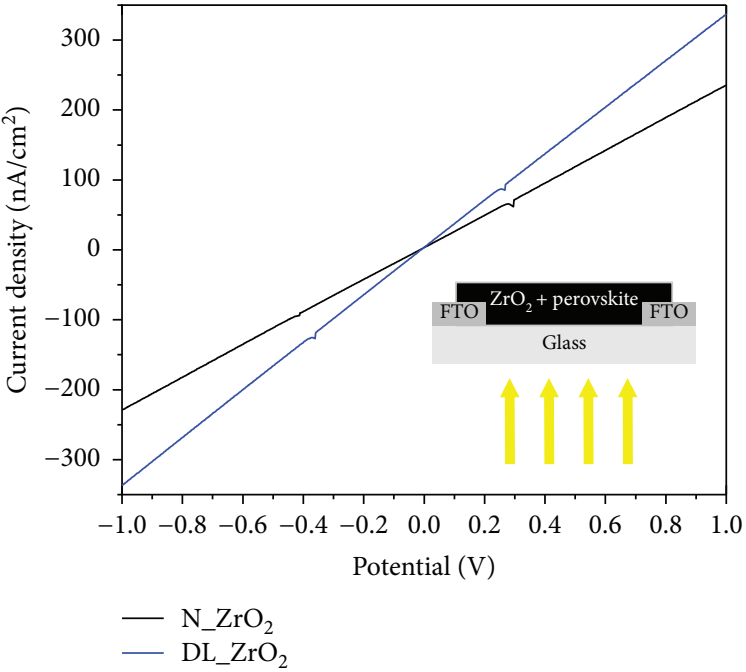

(a)

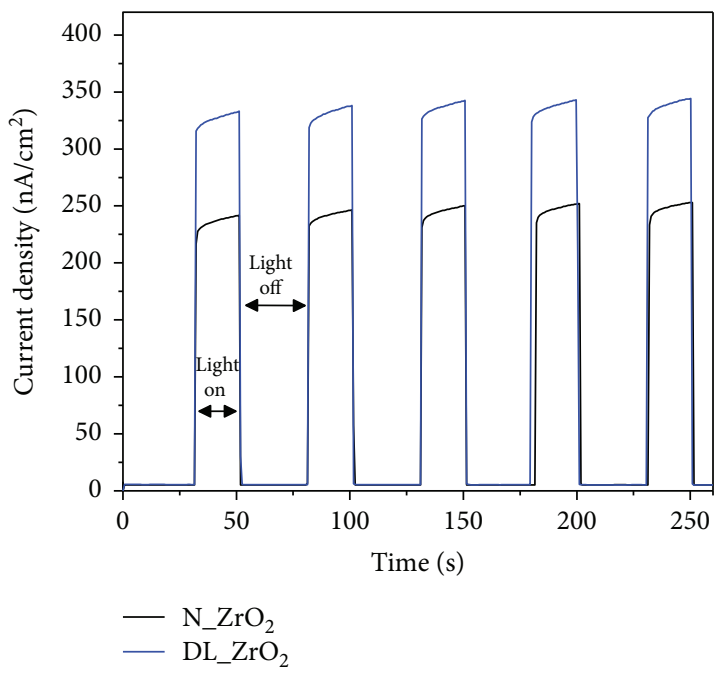

(b)

Figure 7: (a) Current density-voltage curves of photodetectors and (b) transient photocurrent response during on-off illumination at a bias potential of $1 \mathrm{~V}$.

DL_Z $\mathrm{ZO}_{2} /$ perovskite photodetector is $0.043 \mathrm{~mA} / \mathrm{W}$, compared to $0.032 \mathrm{~mA} / \mathrm{W}$ in the case of the $\mathrm{N} \_\mathrm{ZrO}_{2} /$ perovskite photodetector [34]. Figure 7(b) shows five consecutive light on $(20 \mathrm{~s}) /$ light off (30 s) cycles, observing in both cases that the response is very fast and the obtained photocurrent values are highly reproducible. The rise time for both photodetectors was $98 \mathrm{~ms}$, while the fall time was $129 \mathrm{~ms}$ and $133 \mathrm{~ms}$ in the case of $\mathrm{DL} \_\mathrm{ZrO}_{2}$ and $\mathrm{N} \_\mathrm{ZrO}_{2}$, respectively (Figure S3).

The apparent low value of responsivity is attributed to two main reasons: the long distance between the electrodes $(L)$, since the responsivity is inversely proportional to $L^{2}$ [36], and the unfavorable position of the FTO bands for hole extraction. Despite the current simple nonoptimized device structure, a comparison between the two different $\mathrm{ZrO}_{2}$ layers can be made. The increased photocurrent in the case of the $\mathrm{DL} \_\mathrm{ZrO}_{2}$ film can be explained by the increased light absorption of the perovskite layer, due to the efficient backscattering of light by the $\mathrm{ZrO}_{2}$ microparticles. The charge transport ability through the perovskite layer remains the same, as indicated by the similar responses to on/off cycles and the similar values of the rise and fall times. Finally, the presence of different dominant crystal planes of the perovskite (Figure 5) seems to bear no influence on the charge transport ability.

3.5. Performance of Photovoltaic Devices. The effect of the thickness of the spacer layer on the efficiency of carbon- 
TABLE 1: Characteristic photovoltaic properties of carbon-based PSCs prepared with the two different spacer layers, having different thicknesses.

\begin{tabular}{lccccccc}
\hline Spacer & Thickness $(\mu \mathrm{m})$ & Roughness $R_{a}(\mathrm{~nm})$ & $V_{\text {oc }}(\mathrm{V})$ & $J_{\mathrm{sc}}\left(\mathrm{mA} / \mathrm{cm}^{2}\right)$ & FF & $\eta(\%)$ & $R_{\mathrm{s}}\left(\Omega \mathrm{cm}^{2}\right)$ \\
\hline \multirow{2}{*}{$\mathrm{N}_{-} \mathrm{ZrO}_{2}$} & $2.5 \pm 0.4$ & $520 \pm 25$ & $0.59 \pm 0.07$ & $10.9 \pm 0.4$ & $0.41 \pm 0.04$ & $2.2 \pm 0.4$ & $19 \pm 1$ \\
& $4.6 \pm 0.6$ & $575 \pm 25$ & 0.68 & $3.3 \pm 0.7$ & $0.47 \pm 0.05$ & $1.2 \pm 0.2$ & $34 \pm 2$ \\
& $8.7 \pm 0.9$ & $620 \pm 100$ & $0.68 \pm 0.06$ & $2.0 \pm 0.9$ & $0.44 \pm 0.04$ & $0.4 \pm 0.2$ & $53 \pm 9$ \\
\hline & $2.6 \pm 0.2$ & $630 \pm 30$ & $0.67 \pm 0.01$ & $14 \pm 2$ & $0.31 \pm 0.02$ & $2.9 \pm 0.4$ & $29 \pm 5$ \\
$\mathrm{DL}_{-} \mathrm{ZrO}_{2}$ & $3.8 \pm 0.2$ & $660 \pm 70$ & $0.60 \pm 0.08$ & $11.8 \pm 0.7$ & $0.30 \pm 0.02$ & $2.2 \pm 0.6$ & $30 \pm 5$ \\
& $8.3 \pm 0.1$ & $1170 \pm 45$ & $0.63 \pm 0.05$ & $5 \pm 2$ & $0.32 \pm 0.06$ & $1.0 \pm 0.3$ & $62 \pm 5$ \\
\hline
\end{tabular}

based PSCs was examined first. As has been reported elsewhere $[5,13,14]$, the increase of the spacer layer thickness causes drastic decrease of the device efficiency. Indeed, the current data confirm that increasing the thickness of the zirconia NP layer ( $\mathrm{N}_{2} \mathrm{ZrO}_{2}$ ) from 2.5 to $9 \mu \mathrm{m}$ (Table 1) causes decrease of the efficiency from 2.2 to $0.4 \%$, due to the reduction in current density (Figure 8(a)). A thicker zirconia layer provides better insulating properties (Figure S4), since the contact between the carbon layer and the $\mathrm{ZnO}$ NWs was minimized, preventing recombination of carriers at the interface. As a result, a slight increase in the opencircuit potential is observed $[5,13]$, but on the other hand, diffusion of carriers to the carbon electrode becomes impeded and recombination is more likely in bulk, thus limiting the photocurrent and hence the overall efficiency (Figure $8(\mathrm{a})$, inset), while FF is nearly insensitive to film thickness.

When a double-layered $\mathrm{ZrO}_{2}$ film was used as a spacer $\left(\mathrm{DL} \_\mathrm{ZrO}_{2}\right)$, the efficiency was increased in all cases (Figure $8(\mathrm{~b})$ ), due to the enhancement in the photocurrent density, even though the value of FF was inferior compared to that of the $\mathrm{N}_{-} \mathrm{ZrO}_{2}$ film (Table 1). For example, using a double-layered $\mathrm{ZrO}_{2}$ film $2.5 \mu \mathrm{m}$ thick, the efficiency increased by nearly $30 \%$ compared to the $\mathrm{N} \_\mathrm{ZrO}_{2}$. The improvement can be explained by the enhanced lightscattering ability of the double-layered film, as shown in Figure 6, and the improved responsivity of the photodetectors in Figure 7, resulting in higher absorption of light by the perovskite layer and thus higher photocurrent density. The thickness of the scattering layer was $0.5 \pm 0.2 \mu \mathrm{m}$, in all cases.

To improve further the efficiency of the devices, modifications were made in the device construction by reducing the width of the etched area of the substrate (Figure 1), from $5 \mathrm{~mm}$ to few $\mu \mathrm{m}$ [37], whereas the amount of the perovskite precursor solution was reduced from 10 to $5 \mu$ l. To achieve crystallization of the perovskite, the samples were annealed in this case at $60^{\circ} \mathrm{C}$ for $1 \mathrm{~h}$. Figure 9 displays the characteristic $J-V$ curves of the improved devices, having the two different configurations of the $\mathrm{ZrO}_{2}$ layers $\left(\mathrm{N}_{-}\right.$ $\mathrm{ZrO}_{2}$ and $\mathrm{DL} \_\mathrm{ZrO}_{2}$ ), with an average thickness of 2-2.5 $\mu \mathrm{m}$. The results are consistent with previous findings, and the efficiency of the devices is comparable to that of the devices having a similar structure in the literature (Table S1). For example, Wang et al. in [38] have measured an efficiency of 5.5\% for carbon-based PSCs, having $\mathrm{ZnO}$ nanorod arrays as an electron transport layer (ETL), while in [39], the maximum efficiency achieved was 3.6\%. Higher efficiencies have been achieved only in the case where a hole transport medium and a metal electrode have been used (see Table S1 for a comparison of relevant data).

The roughness of the films increases owing to two reasons: (i) due to the thickness increase of the $\mathrm{ZrO}_{2}$ films and (ii) because of the presence of the second layer, consisting of $\mathrm{ZrO}_{2}$ microparticles (Table 1). A rough spacer surface hampers the formation of a good interface between the perovskite and the carbon film. Formation of voids due to incomplete filling with the perovskite cannot be excluded, even though a perovskite layer with larger grains can be formed (Figure 4). Thus, the nonideal interface results in an increased series resistance $\left(R_{\mathrm{s}}\right)$ of the devices (Table 1) and in a lower charge transfer rate at the interface perovskite/carbon [16]. Both factors contribute to the reduced FF of the devices with the DL_ZrO $\mathrm{Zr}_{2}$ film. $R_{\mathrm{s}}$ was derived from the linear fitting using equation (1) and more specifically from the intercept with the $y$-axis (Figure 10) [40]:

$$
-\frac{d V}{d J}=\frac{A k_{B} T}{e} \cdot\left(J_{\mathrm{sc}}-J\right)^{-1}+R_{\mathrm{s}}
$$

$A$ is the ideality factor of the diode, $k_{B}$ is the Boltzmann constant, $T$ is the absolute temperature, $e$ is the elementary charge, and $R_{s}$ represents the series resistance. The above equation is derived from the $I-V$ characteristic of a solar cell, using a one diode model, and holds with the approximation that the shunt or parallel resistance of the solar cell $\left(R_{\mathrm{sh}}\right.$ or $\left.R_{\mathrm{p}}\right)$ is very large compared to the series resistance $\left(R_{\mathrm{s}}\right)$.

As regards the low efficiency of the devices in the present study, a number of reasons can be invoked: first, no additives such as 5-ammoniumvaleric acid (5-AVA) were used in the perovskite precursor solution. With this additive, better pore filling and modification of the ETL/perovskite interface can be achieved [41]. Furthermore, the surface of $\mathrm{ZnO}$ NWs has not been modified in order to suppress charge recombination, as in [38], where $\mathrm{ZnO} / \mathrm{TiO}_{2}$ core shell nanorods were applied in carbon-based PSCs and a two-deposition method was used for the formation of the perovskite layer. Nevertheless, the current study is intended to demonstrate that simple low-cost methods can be employed to prepare devices 

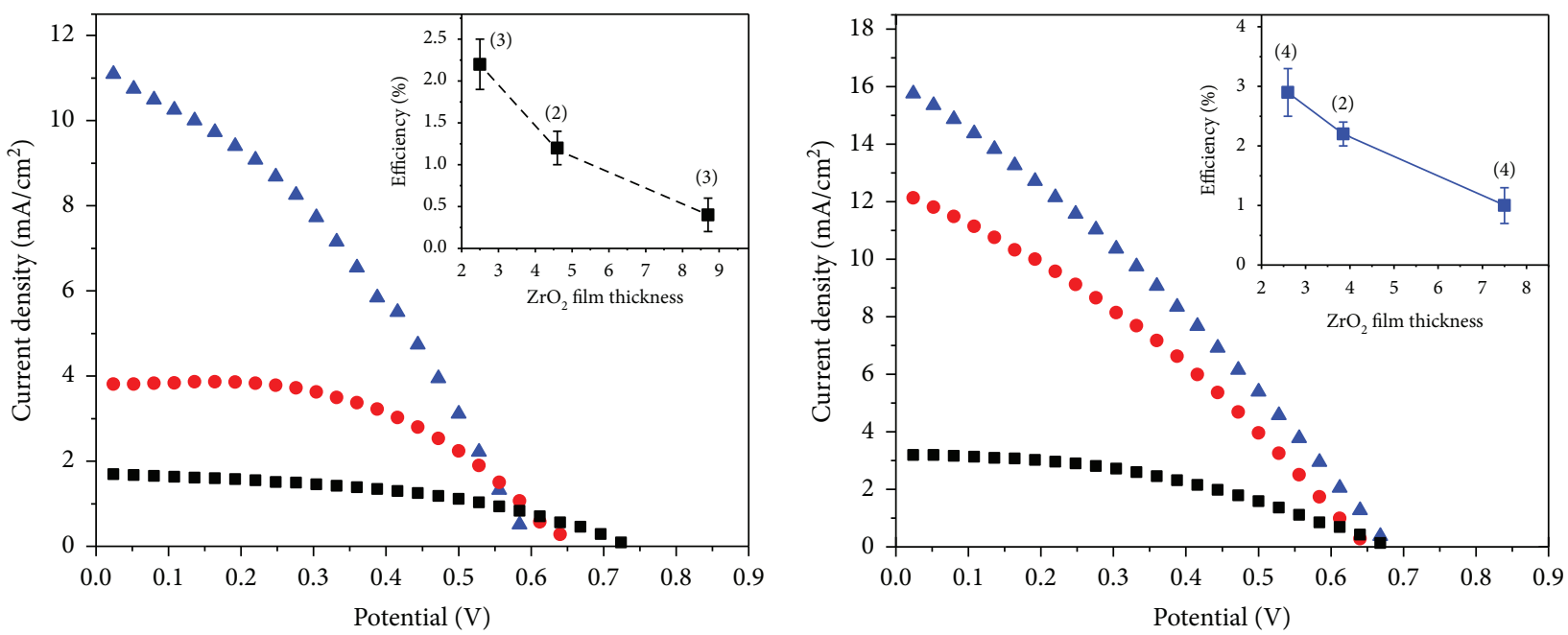

$\mathrm{N} \_\mathrm{ZrO}_{2}$ thickness

DL_ZrO $\mathrm{Zr}_{2}$ thickness

- $2.5 \mu \mathrm{m}$

- $4.6 \mu \mathrm{m}$

- $2.6 \mu \mathrm{m}$

- $3.8 \mu \mathrm{m}$

- $8.3 \mu \mathrm{m}$

(a)

(b)

FIgure 8: Typical $J$ - $V$ curves of PSCs prepared with different spacer thicknesses of (a) $\mathrm{N}_{-} \mathrm{ZrO}_{2}$ films and (b) $\mathrm{DL} \_\mathrm{ZrO}{ }_{2}$ films. Inset graphs: efficiency variation with $\mathrm{ZrO}_{2}$ film thickness and in parentheses number of devices used for calculation of the error bars.

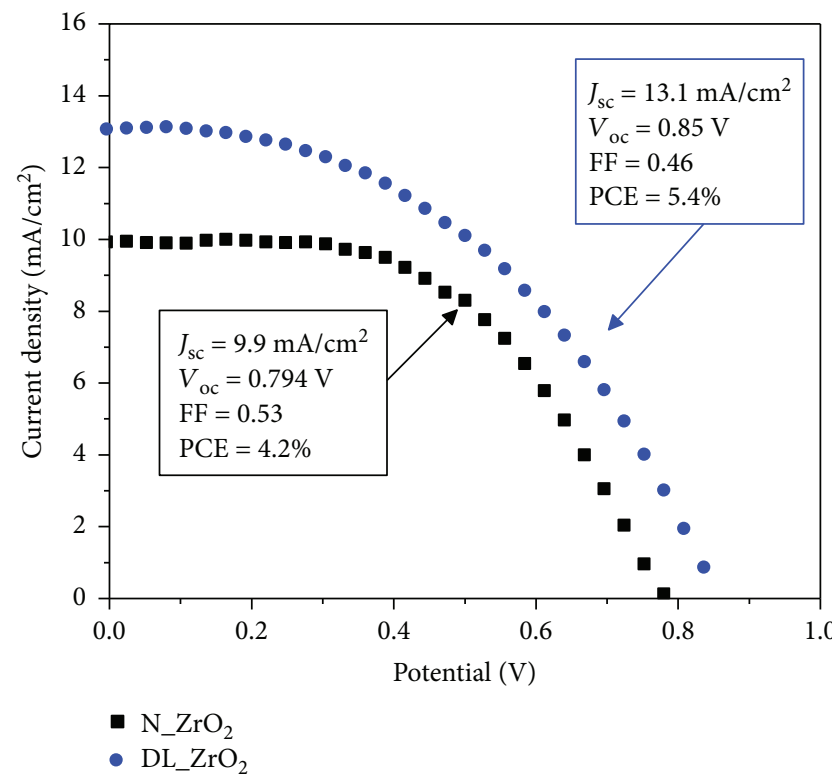

Figure 9: $J$ - $V$ curves of improved PSCs prepared with a $\mathrm{N}_{-} \mathrm{ZrO}_{2}$ film (a) and a $\mathrm{DL} \_\mathrm{ZrO}_{2}$ film (b), as a spacer.

(photodetectors and solar cells) with realistic efficiencies, since the current literature has revealed that the cost and complexity in device preparation are not always commensurate with the increase of efficiency.

\section{Conclusions}

In summary, we have proposed and demonstrated the use of double-layered $\mathrm{ZrO}_{2}$ films, one layer consisting of $\mathrm{ZrO}_{2}$ nanoparticles and the other one of $\mathrm{ZrO}_{2}$ microparticles, acting as spacers in carbon-based PSCs. With this architecture, beyond its common role as an insulator, the $\mathrm{ZrO}_{2}$ film obtains a new role, i.e., that of a light scatterer for more efficient light harvesting by the perovskite layer.

The surface morphology of the double-layered $\mathrm{ZrO}_{2}$ films affects the growth of the perovskite crystals. Larger grains with different dominant crystal planes were grown, since the presence of large-sized $\mathrm{ZrO}_{2}$ particles ensures the availability of free space for perovskite crystal growth. Besides, the scattering ability is enhanced, improving light absorption of the perovskite layer, without affecting its charge transport ability, as observed by measuring the responsivity and the rise and fall times of photodetectors, based on a $\mathrm{ZrO}_{2}$ /perovskite system.

The presence of a double-layered $\mathrm{ZrO}_{2}$ film as a spacer layer in carbon-based PSCs resulted in an increased photocurrent density, due to the better light-harvesting efficiency. The observed changes depend on the $\mathrm{ZrO}_{2}$ film thickness and the surface roughness. The increased surface roughness of the double-layered $\mathrm{ZrO}_{2}$ films prevents the formation of a smooth interface between the $\mathrm{ZrO}_{2}$ and the carbon layer, resulting in an increased series resistance of the devices and a lower FF, compared to devices having a conventional spacer layer. However, the overall effect of the DL_ $\mathrm{ZrO}_{2}$ film in the efficiency of the resulting devices is certainly positive, as an increase in the efficiency reaching up to $30 \%$ is observed. The present work provides evidence that the $\mathrm{ZrO}_{2}$ film used in carbon-based PSCs can affect significantly the device performance, not only acting as a simple insulator layer but as a light scatterer as well. 


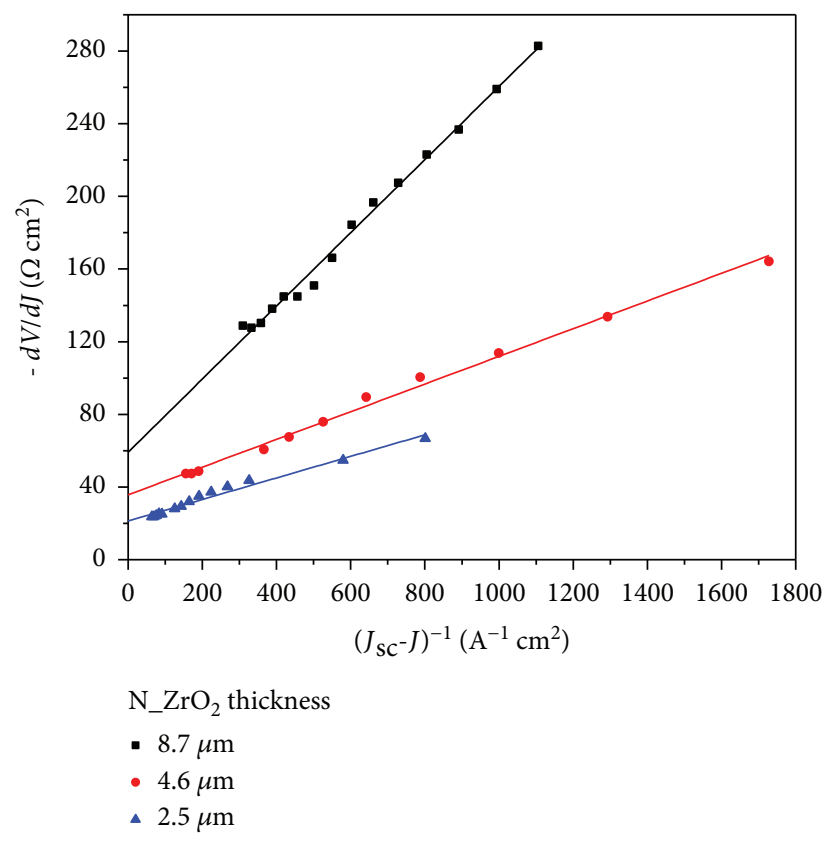

(a)

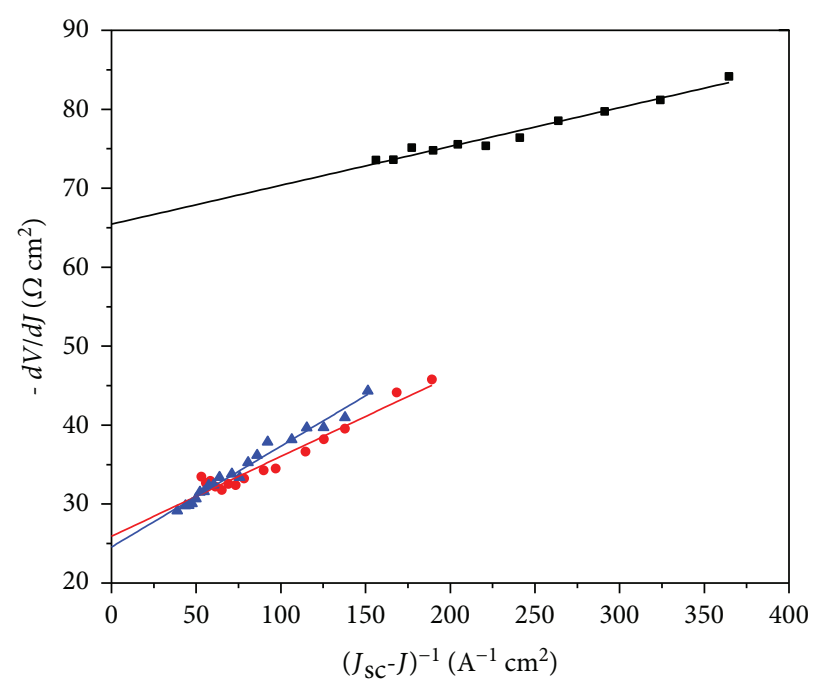

DR_ZrO $\mathrm{Zr}_{2}$ thickness

- $8.3 \mu \mathrm{m}$

- $3.8 \mu \mathrm{m}$

$\triangle 2.6 \mu \mathrm{m}$

Figure 10: Typical plots of $-d V / d J$ vs. $\left(J_{\text {sc }}-J\right)^{-1}$ of PSCs, having (a) a $\mathrm{N}_{-} \mathrm{ZrO}_{2}$ film as a spacer with different thicknesses and (b) a DL_ZrO 2 film as a spacer with different thicknesses.

\section{Data Availability}

The (SEM images, graphs) data used to support the findings of this study are available from the corresponding author upon request.

\section{Conflicts of Interest}

The authors declare that they have no conflicts of interest.

\section{Acknowledgments}

Dr. Kalarakis Alexandros is acknowledged for recording the SEM images at the Technological Educational Institute of Western Greece. George Syrrokostas acknowledges the financial support from the IKY Scholarship Programs, through the Operational Program "Strengthening PostDoctoral Research, Human Resources Development Program, Education and Lifelong Learning," cofinanced by the European Social Fund (ESF) and the Greek government. S.N.Y. acknowledges support by the project "AENAO-Materials and Processes for Energy and Environmental Applications" (MIS 5002556) which is implemented under the "Action for the Strategic Development on the Research and Technological Sector," funded by the Operational Programme "Competitiveness, Entrepreneurship and Innovation" (NSRF 2014-2020) and cofinanced by Greece and the European Union (European Regional Development Fund).

\section{Supplementary Materials}

Figure S1: grain size distribution of a $\mathrm{ZrO}_{2}$ film using a $\mathrm{ZrO}_{2}$ powder consisting of microparticles (Cerac Z-1074). Figure S2: XRD pattern of the perovskite layer deposited on the surface of the two different $\mathrm{ZrO}_{2}$ layers. Figure S3: transient photocurrent response during on-off illumination at a bias potential of $1 \mathrm{~V}$. Figure S4: typical $J-V$ curves prepared with a N_ZrO2 film as a spacer with different thicknesses, before the deposition of the perovskite. Table S1: materials and efficiency of perovskite solar cells based on $\mathrm{ZnO}$ as ETL. (Supplementary Materials)

\section{References}

[1] M. A. Green, Y. Hishikawa, E. D. Dunlop, D. H. Levi, J. Hohl-Ebinger, and A. W. Y. Ho-Baillie, "Solar cell efficiency tables (version 52)," Progress in Photovoltaics: Research and Applications, vol. 26, no. 7, pp. 427-436, 2018.

[2] G. Peng, X. Xu, and G. Xu, "Hybrid organic-inorganic perovskites open a new era for low-cost, high efficiency solar cells," Journal of Nanomaterials, vol. 2015, 10 pages, 2015.

[3] H. Chen and S. Yang, "Stabilizing and scaling up carbon-based perovskite solar cells," Journal of Materials Research, vol. 32, no. 16, pp. 3011-3020, 2017.

[4] Z. Meng, D. Guo, J. Yu, and K. Fan, "Investigation of $\mathrm{Al}_{2} \mathrm{O}_{3}$ and $\mathrm{ZrO}_{2}$ spacer layers for fully printable and holeconductor-free mesoscopic perovskite solar cells," Applied Surface Science, vol. 430, pp. 632-638, 2018.

[5] T. Liu, L. Liu, M. Hu et al., "Critical parameters in $\mathrm{TiO}_{2} / \mathrm{ZrO}_{2} /-$ carbon-based mesoscopic perovskite solar cell," Journal of Power Sources, vol. 293, pp. 533-538, 2015. 
[6] H. Chen and S. Yang, "Carbon-based perovskite solar cells without hole transport materials: the front runner to the market?," Advanced Materials, vol. 29, no. 24, 2017.

[7] S. S. Mali and C. K. Hong, "P-i-n/n-i-p type planar hybrid structure of highly efficient perovskite solar cells towards improved air stability: synthetic strategies and the role of p-type hole transport layer (HTL) and n-type electron transport layer (ETL) metal oxides," Nanoscale, vol. 8, no. 20, pp. 10528-10540, 2016.

[8] Y. Rong, L. Liu, A. Mei, X. Li, and H. Han, "Beyond efficiency: the challenge of stability in mesoscopic perovskite solar cells," Advanced Energy Materials, vol. 5, no. 20, article 1501066, 2015.

[9] Z. Ku, Y. Rong, M. Xu, T. Liu, and H. Han, "Full printable processed mesoscopic $\mathrm{CH}_{3} \mathrm{NH}_{3} \mathrm{PbI}_{3} / \mathrm{TiO}_{2}$ heterojunction solar cells with carbon counter electrode," Scientific Reports, vol. 3, no. 1, article 3132, 2013.

[10] S. Ito, G. Mizuta, S. Kanaya et al., "Light stability tests of $\mathrm{CH} 3 \mathrm{NH} 3 \mathrm{PbI} 3$ perovskite solar cells using porous carbon counter electrodes," Physical Chemistry Chemical Physics, vol. 18, no. 39, pp. 27102-27108, 2016.

[11] X. Li, M. Tschumi, H. Han et al., "Outdoor performance and stability under elevated temperatures and long-term light soaking of triple-layer mesoporous perovskite photovoltaics," Energy Technology, vol. 3, no. 6, pp. 551-555, 2015.

[12] A. Priyadarshi, L. J. Haur, P. Murray et al., "A large area (70 $\mathrm{cm}^{2}$ ) monolithic perovskite solar module with a high efficiency and stability," Energy \& Environmental Science, vol. 9, no. 12, pp. 3687-3692, 2016.

[13] Y. Hu, S. Si, A. Mei et al., "Stable large-area $\left(10 \times 10 \mathrm{~cm}^{2}\right)$ printable mesoscopic perovskite module exceeding $10 \%$ efficiency," Solar RRL, vol. 1, no. 2, article 1600019, 2017.

[14] A. Priyadarshi, A. Bashir, J. T. Gunawan et al., "Simplified architecture of a fully printable perovskite solar cell using a thick zirconia layer," Energy Technology, vol. 5, no. 10, pp. 1866-1872, 2017.

[15] T. Liu, Y. Rong, Y. Xiong et al., "Spacer improvement for efficient and fully printable mesoscopic perovskite solar cells," RSC Advances, vol. 7, no. 17, pp. 10118-10123, 2017.

[16] H. Chen, Z. Wei, H. He, X. Zheng, K. S. Wong, and S. Yang, "Solvent engineering boosts the efficiency of paintable carbon-based perovskite solar cells to beyond 14\%," Advanced Energy Materials, vol. 6, no. 8, 2016.

[17] S. Hore, C. Vetter, R. Kern, H. Smit, and A. Hinsch, "Influence of scattering layers on efficiency of dye-sensitized solar cells," Solar Energy Materials \& Solar Cells, vol. 90, no. 9, pp. 11761188, 2006.

[18] G. Syrrokostas, K. Govatsi, and S. N. Yannopoulos, "Highquality, reproducible $\mathrm{ZnO}$ nanowire arrays obtained by a multiparameter optimization of chemical bath deposition growth," Crystal Growth \& Design, vol. 16, no. 4, pp. 2140-2150, 2016.

[19] G. Syrrokostas, G. Leftheriotis, and P. Yianoulis, "Effect of acidic additives on the structure and performance of $\mathrm{TiO}_{2}$ films prepared by a commercial nanopowder for dyesensitized solar cells," Renewable Energy, vol. 72, pp. 164173, 2014.

[20] G. Syrrokostas, A. Antonelou, G. Leftheriotis, and S. N. Yannopoulos, "Electrochemical properties and long-term stability of molybdenum disulfide and platinum counter electrodes for solar cells: a comparative study," Electrochimica Acta, vol. 267, pp. 110-121, 2018.
[21] S. N. Basahel, T. T. Ali, M. Mokhtar, and K. Narasimharao, "Influence of crystal structure of nanosized $\mathrm{ZrO}_{2}$ on photocatalytic degradation of methyl orange," Nanoscale Research Letters, vol. 10, no. 1, article 73, 2015.

[22] M. Jafarpour, E. Rezapour, M. Ghahramaninezhad, and A. Rezaeifard, "A novel protocol for selective synthesis of monoclinic zirconia nanoparticles as a heterogeneous catalyst for condensation of 1,2-diamines with 1,2-dicarbonyl compounds," New Journal of Chemistry, vol. 38, no. 2, pp. 676682, 2014.

[23] Z. Xiao, Q. Dong, C. Bi, Y. Shao, Y. Yuan, and J. Huang, "Solvent annealing of perovskite-induced crystal growth for photovoltaic-device efficiency enhancement," Advanced Materials, vol. 26, no. 37, pp. 6503-6509, 2014.

[24] Y. Zhang, Y. Wang, Z. Sun et al., "Large grain growth for holeconductor-free fully printable perovskite solar cells via polyoxometalate molecular doping," Chemical Communications, vol. 53, no. 14, pp. 2290-2293, 2017.

[25] P. Bhatt, K. Pandey, P. Yadav et al., "Investigating the charge carrier transport within the hole-transport material free perovskite solar cell processed in ambient air," Solar Energy Materials \& Solar Cells, vol. 140, pp. 320-327, 2015.

[26] T. Oku, "Crystal structures of $\mathrm{CH} 3 \mathrm{NH} 3 \mathrm{PbI} 3$ and related perovskite compounds used for solar cells," in Solar Cells New Approaches and Reviews, pp. 77-101, InTech, 2015.

[27] X. Guo, C. McCleese, C. Kolodziej, A. C. S. Samia, Y. Zhao, and C. Burda, "Identification and characterization of the intermediate phase in hybrid organic-inorganic MAPbI3perovskite," Dalton Transactions, vol. 45, no. 9, pp. 3806-3813, 2016.

[28] I. Dhiaputra, B. Permana, Y. Maulana, Y. D. Inayatie, Y. R. Purba, and A. Bahtiar, "Composition and crystal structure of perovskite films attained from electrodes of used car battery," in AIP Conf. Proc., 2016.

[29] L. Zhu, Y. L. Zhao, X. P. Lin, X. Q. Gu, and Y. H. Qiang, "The effect of light-scattering layer on the performance of dyesensitized solar cell assembled using $\mathrm{TiO}_{2}$ double-layered films as photoanodes," Superlattices and Microstructures, vol. 65, pp. 152-160, 2014.

[30] T. Watson, C. Charbonneau, D. Bryant, and D. Worsley, "Acid treatment of titania pastes to create scattering layers in dyesensitized solar cells," International Journal of Photoenergy, vol. 2012, 8 pages, 2012.

[31] N. M. Nursam, J. Hidayat, Shobih, E. S. Rosa, and L. M. Pranoto, "A comparative study between titania and zirconia as material for scattering layer in dye-sensitized solar cells," Journal of Physics Conference Series, vol. 1011, p. 012003, 2018.

[32] M. K. Son, H. Seo, S. K. Kim et al., "Analysis on the lightscattering effect in dye-sensitized solar cell according to the $\mathrm{TiO}_{2}$ structural differences," International Journal of Photoenergy, vol. 2012, Article ID 480929, 8 pages, 2012.

[33] Q. Wang, S. Liu, Y. Ming et al., "Improvements in printable mesoscopic perovskite solar cells via thinner spacer layers," Sustainable Energy \& Fuels, vol. 2, no. 11, pp. 2412-2418, 2018.

[34] M. He, Y. Chen, H. Liu, J. Wang, X. Fang, and Z. Liang, "Chemical decoration of $\mathrm{CH} 3 \mathrm{NH} 3 \mathrm{PbI} 3$ perovskites with graphene oxides for photodetector applications," Chemical Communications, vol. 51, no. 47, pp. 9659-9661, 2015.

[35] Y. Lee, J. Kwon, E. Hwang et al., "High-performance perovskite-graphene hybrid photodetector," Advanced Materials, vol. 27, no. 1, pp. 41-46, 2015. 
[36] Y. Wang, Z. Xia, S. Du et al., "Solution-processed photodetectors based on organic-inorganic hybrid perovskite and nanocrystalline graphite," Nanotechnology, vol. 27, no. 17, article 175201, 2016.

[37] F. De Rossi, J. A. Baker, D. Beynon et al., "All printable perovskite solar modules with $198 \mathrm{~cm}^{2}$ active area and over $6 \%$ efficiency," Advanced Materials Technologies, vol. 3, no. 11, article 1800156, 2018.

[38] B. X. Wang, T. F. Liu, Y. B. Zhou et al., "Hole-conductor-free perovskite solar cells with carbon counter electrodes based on ZnO nanorod arrays," Physical Chemistry Chemical Physics, vol. 18, no. 39, pp. 27078-27082, 2016.

[39] H. Wang, L. Yan, J. Liu, J. Li, and H. Wang, "Fabrication of well-aligned $\mathrm{ZnO}$ nanorod photoanodes for perovskite solar cells," Journal of Materials Science: Materials in Electronics, vol. 27, no. 7, pp. 6872-6880, 2016.

[40] J. Shi, J. Dong, S. Lv et al., "Hole-conductor-free perovskite organic lead iodide heterojunction thin-film solar cells : high efficiency and junction property," Applied Physics Letters, vol. 104, no. 6, pp. 063901-063904, 2014.

[41] A. Mei, X. Li, L. Liu et al., "A hole-conductor-free, fully printable mesoscopic perovskite solar cell with high stability," Science, vol. 345, no. 6194, pp. 295-298, 2014. 


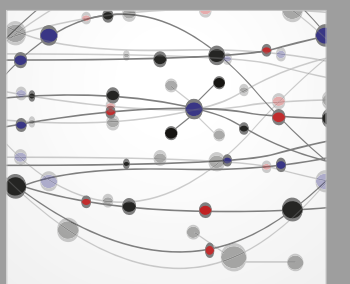

The Scientific World Journal
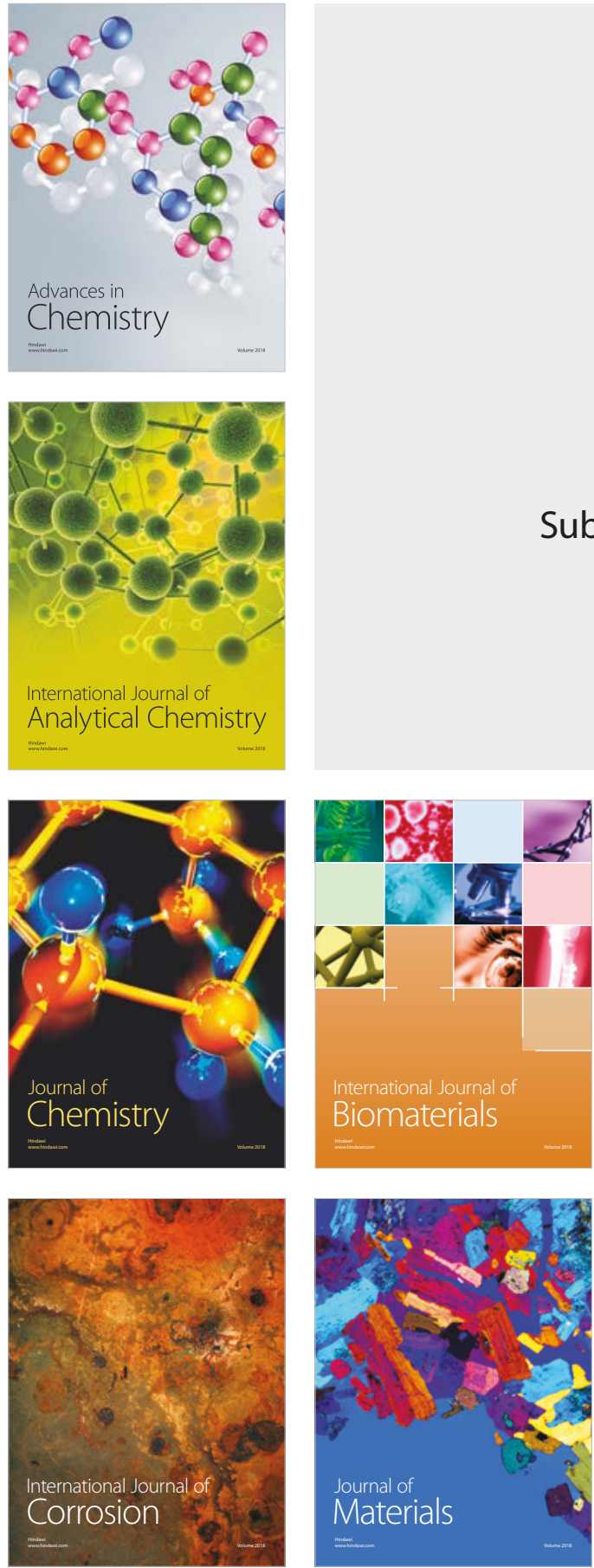

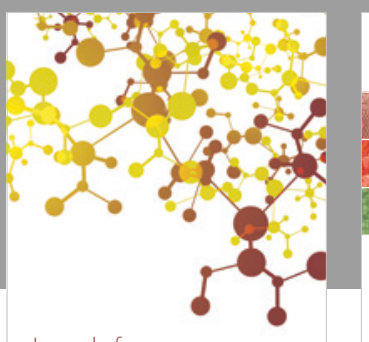

Journal of

Applied Chemistry
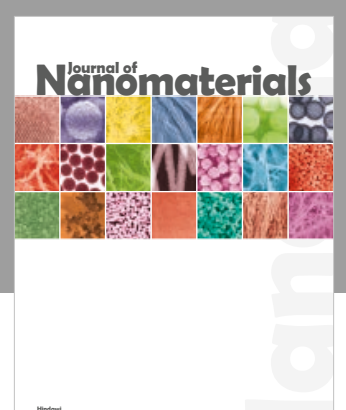

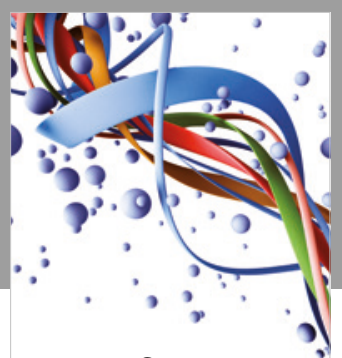

Scientifica

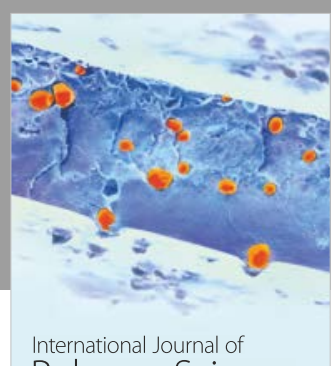

Polymer Science

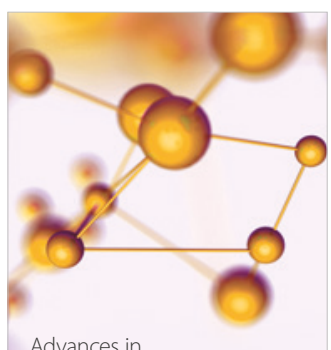

Physical Chemistry
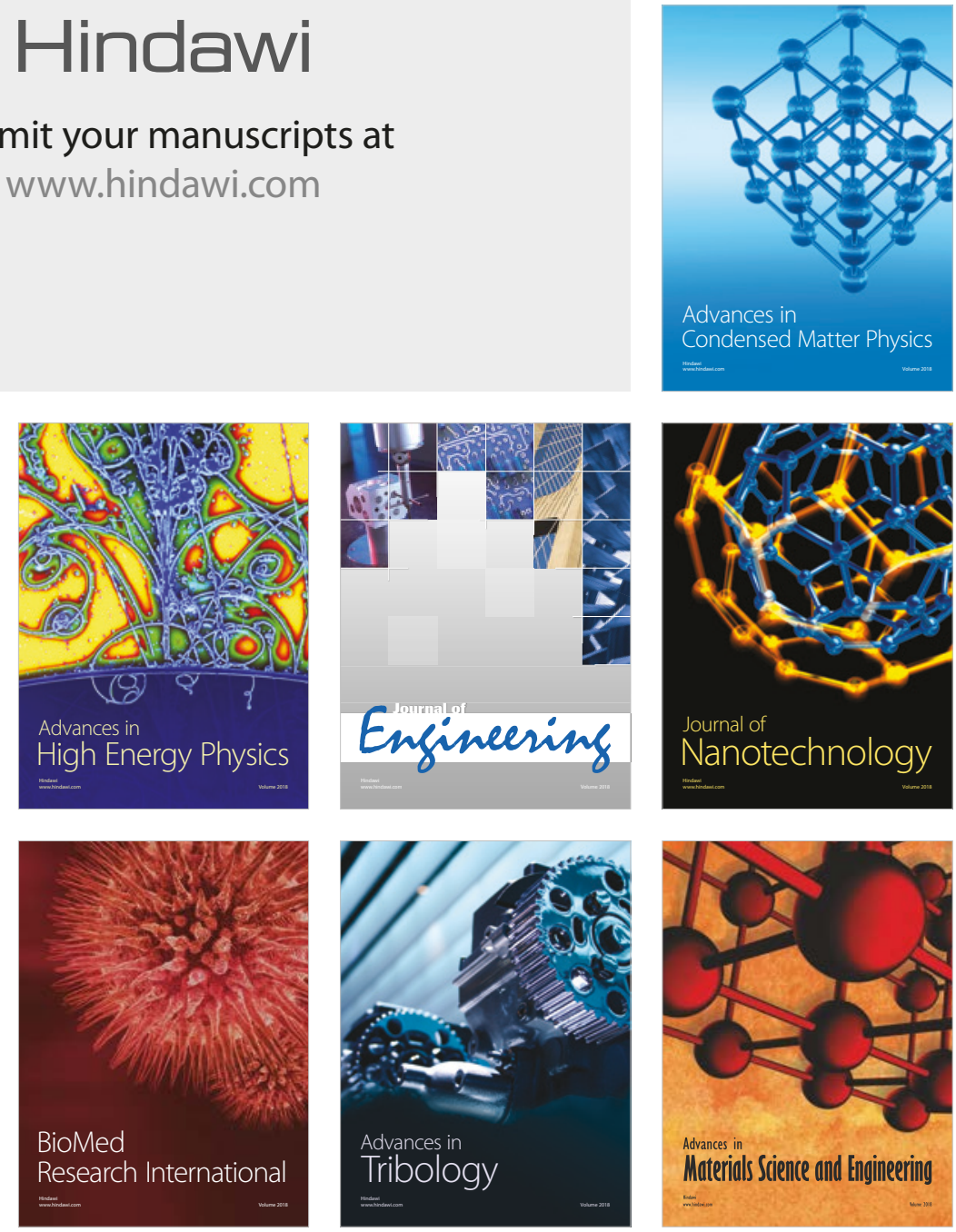